\title{
Experience in recruiting youths in HIV vaccine trials in Tanzania: the TaMoVac 01 study
}

\author{
T Massawa*, A Swalehe, D Niima \\ From AIDS Vaccine 2012 \\ Boston, MA, USA. 9-12 September 2012
}

\section{Background}

Muhimbili University of Health Allied Science has been conducting HIV Vaccine trials since 2007. The first trial the HIVIS 03 study began in February 2007 that recruited Police. We believe that the population to be prevented from HIV would be youths. We describe our experice in recruiting youths.

\section{Methods}

Sensitization meetings were conducted at the youth clinic.Pre screening workshops were conducted at Muhimbili National Hospital. Youths who showed interest in volunteering were asked to come for screening at the clinic located at Muhimbili National Hospital.

\section{Results}

Enrolment of youth volunteers in the study was not a problem. Among 60 volunteers recruited 25 were youths. We recruited 5 males and 20 females who were recruited over 1 year. There were challenges encountered in recruiting youths. These included inability for independent decision to join the trail though we noted that the parents were supportive after being well informed. 4/25 youths relocated in search for jobs this resulted in additional costs to call in the volunteer for safety assessments. $2 / 25$ female youths became pregnant during the study period.

\section{Conclusion}

We noted that it was easy to recruit youths in the trial after the parents were well informed. However, there is need for continuous education so as to address pregnancy prevention.

Muhimbili University of Health and Allied Sciences, Dar es Salaam, Tanzania, United Republic of
Published: 13 September 2012

doi:10.1186/1742-4690-9-S2-P125

Cite this article as: Massawa et al:: Experience in recruiting youths in HIV vaccine trials in Tanzania: the TaMoVac 01 study. Retrovirology 2012 9(Suppl 2):P125.
Submit your next manuscript to BioMed Central and take full advantage of:

- Convenient online submission

- Thorough peer review

- No space constraints or color figure charges

- Immediate publication on acceptance

- Inclusion in PubMed, CAS, Scopus and Google Scholar

- Research which is freely available for redistribution
C Biomed Central 